\title{
Model Pembuatan Peraturan Daerah Berbasis Syariat Islam (Perspektif Legislative Drafting Kontemporer)
}

\author{
Jazim Hamidi dan Tatang Astarudin
}

\begin{abstract}
The altemative model of producing Local Regulation (PERDA) which are based on islamic Laws constitutes a new, urgent concept in the context of legislative draffing renewal. Because the process of producing the regulations (from the planning unto its soccialization/ evaluation) must follow the principles of generating good and democratic laws, it must also accommodate Islamic values and principles. While the word "Islamic Laws" can be understood both inclusively and exclusively.
\end{abstract}

\section{Pendahuluan}

Otonomi daerah tidak dapat dipandang sebagai agenda yang terpisah dari agenda besar demokratisasi kehidupan bangsa. Konsekuensi logis dari cara pandang tersebut, kebijakan otonomi daerah itu harus diposisikan sebagai instrumen desentralisasidemokratisasi. Dalam kaitan ini, otonomi daerah bukanlah tujuan, melainkan cara dan sarana demokratis untuk mewujudkan kemandirian, kesejahteraan, dan keadilan bagi seluruh rakyat tanpa kecuali. Maka tak pelak pemberlakuan otonomi daerah berdasarkan Undang-Undang No. 22 Tahun 1999 dan Undang-Undang No. 25 Tahun 1999 telah mendorong terjadinya berbagai perubahan paradigma mendasar di daerah. Pola pemerintahan telah berubah dari konsep yang sentralistik menjadi desentralistik disertai munculnya harapan suburnya iklim demokratis di daerah.

Demokratisasi di daerah mengandung makna semakin menguatnya partisipasi rakyat dalam proses-proses politik dan pembangunan di daerah, termasuk partisipasi rakyat dalam "proses pembuatan peraturan perundangundangan tingkat daerah". Wujud partisipasi rakyat dimaksud dapat dilihat dari intensitas keterlibatan rakyat dalam mempengaruhi (influencing) proses pembuatan Peraturan Daerah (Perda) di Dewan Perwakilan Rakyat Daerah (DPRD), serta proses mengawasi (monitoring) dan menilai (evaluating) implementasi Perda oleh Pemerintah Daerah.

Gelombang demokratisasi yang dibawa oleh momentum otonomi daerah tersebut, di antaranya telah mendorong umat Islam di 
beberapa daerah (sebut saja misalnya Tasikmalaya, Garut, dan Cianjur, untuk wilayah Jawa Barat) telah mendesak DPRD-nya supaya menerapkan "syariat Islam" di daerahnya melalui tuntutan pembuatan berbagai "Perda Berbasis Syariat". Keinginan tersebut semakin menguat ketika secara yuridis formal melalui Undang-Undang No. 44 Tahun 1999 jo Undang-Undang No. 18 Tahun 2001, Pemerintah "memperkenankan" pelakanaan Syariat Islam di Propinsi Nanggroe Aceh Darussalam (NAD).

Formalisasi dan pemberlakuan syariat Islam dalam konteks Negara Kesatuan Republik Indonesia memang tidak semudah pengucapannya, sebab pada tataran konsep, proses, dan konsekuensi hukum maupun nolitiknya masih harus dicarikan titik riersamaan pandang terlebih dahulu. Secara konsepsional, ediom tentang "syariat Islam" masih terus diperdebatkan; apakah mengikuti pola pandang yang inklusif, eksklusif, atau mungkin yang sekuler. Demikian juga proses dan konsekuensi dari formalisasi syariat Islampun mengalami pasang dan surut dalam pembaharuan sistem ketatanegaraan Indonesia.

Sejarah telah mencatat, tidak sedikit konsekuensi sosial-politik, bahkan jiwa dan raga yang harus dibayar oleh umat Islam yang menghendaki formalisasi syariat islam di bumi nusantara. Hingga saat ini, perjuangan untuk memberlakukan syariat islam dengan cara mengamandemen Pasal 29 UUD 1945 dapat dikatakan "belum berhasil," karena sebagian besar fraksi di MPR-RI sepakat untuk tidak merubah pasal tersebut. Demikian juga komentar pro-kontra mengenai masalah ini terus bergulir di masyarakat.

Menanggapi realitas tuntutan politik umat
Islam pada skala nasional maupun lokal di beberapa daeraı yang bersemangat untuk menerapkan atau memasukkan nilai-nilai syariat Islam dalam berbagai peraturan (Perda untuk tingkat Daerah), di satu pihak harus dipandang sebagai hal yang wajar, karena realitas umat Islam yang mayoritas sedang mengekspresikan rasa hukum dan keadilannya yang hidup. Di pihak lain, ekspresi nilai dan semangat juang semacam ini harus dibangun dengan pemikiran/konsep yang mendalam dan serius. Sebab realitas ummat Isiam di Indonesia (termasuk di Nanggroe Aceh Darussalam sekalipun) belum memiliki pedoman konseptual menyangkut "Model Pembuatan Perda (untuk Aceh disebut qanun) Yang Berbasis Syariat Islam."

Maksud dari model pembuatan Perda berbasis syariat Islam di sini adalah di satu sisi sesuai dengan prinsip-prinsip pembuatan peraturan perundang-undangan yang baik dan demokratis. Pada sisi yang lain proses pembuatannya (mulai dari tahap perencanaan, perancangan, pembahasan, substansi, pengundangan, dan evaluasinya) mampu mengakomodasi nilai-nilai syariat Islam. Karena itu upaya alternatif rekayasa model pembuatan Perda Berbasis Syariat Islam ini mempunyai makna strategis bagi pembaruan sistem hukum nasional (lokal) di masa-masa yang akan datang.

Adapun lokasi penelitian ini ditakukan di Kabupaten Garut, Cianjur, dan Tasikmalaya Jawa Barat, sedangkan objek kajian yang dijadikan bahan analisisnya adalah berupa Perda-perda yang disinyalir terkait erat dengan syariat Islam. Beberapa Perda dimaksud adalah Perda Kabupaten Tasikmalaya No. 01 Tahun 2000 tentang Pemberantasan Pelacuran; Perda Kabupaten Garut No. 06 
Tahun 2000 tentang Pelanggaran Kesusilaan; dan Perda Kabupaten Cianjur No. 21 Tahun 2000 tentang Larangan Pelacuran.

Permasalahan yang muncul adalah, di era transisi dari sistem demokrasi perwakilan (representative democracy) ke sistem demokrasi partisipatif (partisipative democracy) seperti sekarang ini, upaya mengakomodasi aspirasi dan tuntutan masyarakat tersebut akan sangat tergantung pada "kemampuan" dan "kemauan" anggota DPRD. Kongkretnya, untuk menyikapi maraknya tuntutan aspirasi masyarakat yang ingin menerapkan syariat Islam tersebut, secara internal diperlukan peningkatan kualitas ilmu, peran, dan tanggung jawab anggota DPRD, khususnya di bidang legislative drafting (teknik perancangan draf peraturan perundangundangan). Mereka juga dituntut lebih proaktif, kreatif, serta berani dalam memperjuangkan agenda pembaruan hukum Islam khususnya, dan pembaharuan sistem pemerintahan daerah pada umumnya. Permasalahan lain adalah seperti apakah model pembuatan Perda berbasis syariat Islam yang akan ditawarkan itu. Tentu grend desain yang hendak ditawarkan ini harus didialogkan terusmenerus secara terbuka, termasuk melalui tulisan ini.

Tujuan dari kajian ini diharapkan, secara teoritis dapat berguna sebagai sumber informasi untuk kajian/penelitian lanjutan bagi pembaruan legislative drafting daerah, sekaligus mempertegas pemahaman bahwa hukum tidak dapat dilepaskan dari kondisi sosial yang terjadi pada saat perencanaan, pembuatan, dan implementasinya. Secara praktis, kajian ini diharapkan berguna bagi umat Islam pada umumnya dan kalangan legislatif (DPRD)dan eksekutif daerah, serta para praktisi hukum pada khususnya dalam upaya transformasi formalisasi atau substansialisasi syariat Islam melalui kebijakan pembuatan Perda atau peraturan yang lain di daerah.

\section{Konsepsi Teoretik yang Dibangun}

Secara konsepsional, ada beberapa teori atau konsep yang bisa dijadikan accuan dasar dalam kajian tentang rekayasa model pembuatan Perda yang berbasis syariat Islan. ini. Di antaranya; teori "negara berdasar atas: hukum" (Rechtsstaat), teori "Trias Politica, ${ }^{\text {"2 }}$ "prinsip-prinsip pembuatan peraturan perundang-undangan yang baik, ${ }^{n 3}$ dan "konsepsi syariat Islam itu sendiri (baik pola yang inklusif dan eksklusif). ${ }^{\text {" }}$ Penulis tidak bermaksud mengelaborasikan masingmasing teori tersebut satu persatu, melainkan hanya akan mengilustrasikan secara singkat ke dalam komponen kerangka pikir yang

'Lihat dalam A. Hamid S. Attamimi, "Peranan Keputusan Presiden Dalam Penyelenggaraan Pemerintah Negara," Disertasi, (Jakarta: Ul, 1990), hlm. 1-4 dan 9.

"Sri Soemantri, "Beberapa Catatan terhadap Proposal Penelitian tentang Aspek Hukum InisiatifDPR dalam Penyusunan Undanc-undang," Makalah tidak diterbitkan, 1998, hlm. 3.

${ }^{3}$ Bagir Manan, Dasar-dasar Perundang-undangan Indonesia (Jakarta: ind-Hilco, 1992), him. 13-20.

"Abul A'la al-Maududi, "The Islamic Law and Constitution," (diterjemahkan) Hukum dan Konstitusi: Sistem Politik Islam (Bandung: Mizan, 1994), hlm. 23. 
tersistematisir di bawah ini.

Kerangka pikir yang hendak dibangun dimaksud diklasifikasi lebih lanjut sebagai berikut:

(1) Komponen konstitusional; sebagai konsekuensi negara berdasar atas hukum (Rechstaat), maka setiap pembuatan peraturan perundang-undangan (termasuk peraturan perundang-undangan tingkat daerah), harus didasari oleh faham konstitusional yang jelas.

(2) Komponen politik hukum; landasan konstitusional tersebut dalam tarap implementasinya akan melahirkan politik hukum daerah yang antara lain berisi kehendak dan arah kebijakan pembaruan dan pengembangan hukum di daerah yang responsifi, demokratis, dan partisipatif.

(3) Komponen program legislasi daerah; agar kehendak pembaruan dan pengembangan hukum di daerah dapat terwujud secara kongkret, maka diperlukan program legislasi daerah yang terencana, terpadu, dan holistik.

(4) Komponen bahan baku dalam proses penyusunan program legislasi daerah adalah berbagai asas, kaidah, dan nilainilai serta pandangan yang hidup dan berkembang efektif di masyarakat (iving law), seperti sistem dan tatanan hukum nasional, hukum adat, termasuk hukum Islam. Hal itu merupakan peluang atau sebaliknya menjadi ancaman bagi daerah. Sebab, jika salah memaknai, misalnya semata-mata didasarkan pada kepentingan sesaat kedaerahan (eforia kedaerahan) dan tendensi politis untuk menonjolkan identitas suku, kelompok, atau agama tertentu, maka yang terjadi bukan pembaruan dan pengembangan hukum yang harmonis-demokratis, letapi yang terjadi adalah hukum yang elitis, represif, anarkis, dan egoisme kedaerahan.

(5) Komponen aspirasi masyarakat. Aspirasi masyarakat daerah penting diperhatikan sekaligus harus selektif, karena masingmasing daerah mempunyai karakter dan ciri yang berbeda-beda. Tuntutan penerapan syariat Islam misalnya, sangat tergantung pada "kemampuan" dan "kemauan" eksekutif dan legislatif daerah dalam menyerap dan menuangkan aspirasi masyarakat tersebut dalam bentuk Perda atau bentuk-bentuk lainnya.

(6) Komponen penerapan syariat Islam. Konsepsi penerapan syariat islam di sini apakah dalam lingkup pengertian yang inklusif atau eksklusif. Jika inklusif, berarti penerapan syariat dalam konteks substantifnya atau nilai-nilai dasar islam yang diperjuangkan untuk menjadi dasar pengaturan dalam berbagai Perda. Jika eksklusif, berarti yang diperjuangkan adalah keinginan formalisasi syariat Islam baik dalam bentuk produk peraturan perundang-undangan daerah. Kajian ini, mengikuti pola penerapan syariat Islam dalam arti yang inklusif.

(7) Komponen "Produk Hukum Daerah Yang Berbasis Syariat Islam". Dengan kata lain, upaya untuk mewujudkan semangat otonomi daerah plus semangat keIslaman yang diwujudkan melalui pembuatan berbagai Perda berbasis syariat Islam ini diperlukan sikap demokratis, responsif, dan partisipatif. Pada gilirannya akan tercermin ke dalam produk hukum datrah yang demokratis, etonom, dan responsif. 
Hubungan antar berbagai komponen tersebut secara skematis dapat dilihat pada bagan di bawah ini: ${ }^{5}$

\section{Bagan 1}

Kerangka Pikir /Teoretik

"Model Pembuatan Peraturan Daerah

Berbasis Syariat Islam"
Analisis atas Perda tentang Pelaruran, Case Study

Berdasarkan data yang diperoleh di lapang (Kabupaten Garut, Cianjur, dan Tasikmalaya) bahwa dalam kurun waktu 1999 - awal 2003, terdapat kurang lebih 308 Perda yang berhasil mereka buat; Kabupaten Garut telah membuat 103 Perda, Kabupaten Cianjur membuat 82 Perda, dan Kabupaten

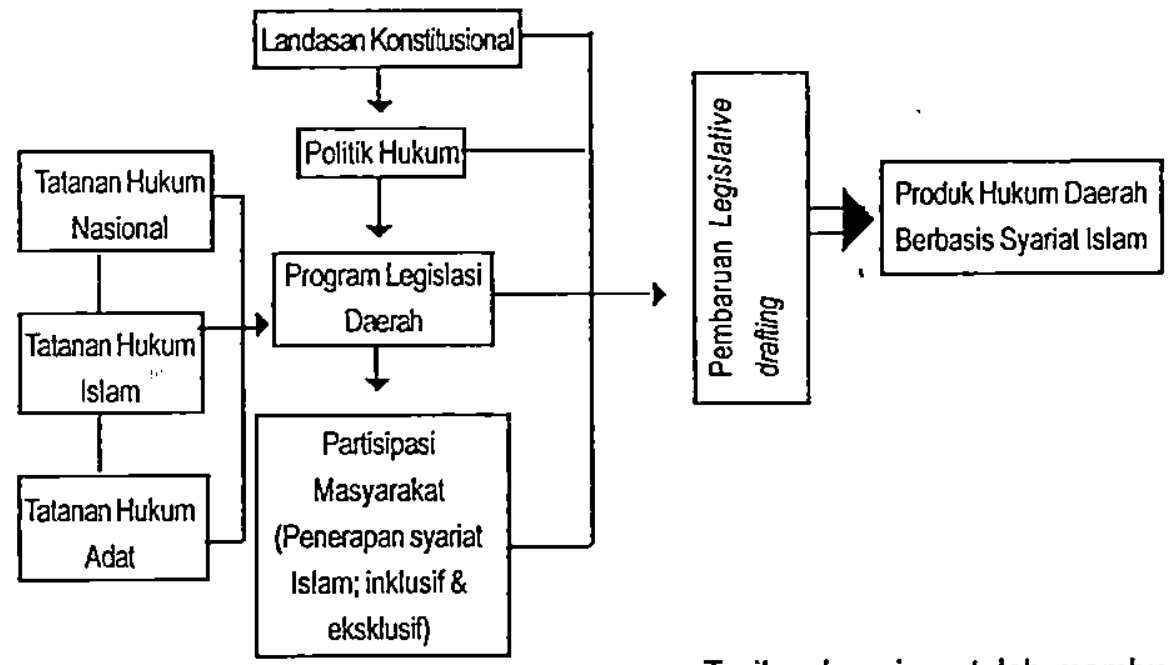

Tasikmalaya juga telah membuat 103 buah Perda. Dari sekian banyak Perda tersebut, Keterangan:

: hubungan langsung

: hubungan fungsional diperoleh hanya 1 Perda yang merupakan hasil inisiatif DPRD, yakni Perda Kabupaten Garut No. 1 Tahun 2003 tentang Pengelolaan Zakat, Infaq, dan Shadaqah. Sedangkan Perda yang dijadikan bahan kajian dalam tulisan ini adalah Perda tentang larangan $p \epsilon^{\prime} 3 c u r a n$, yang ketiga daerah tersebut juga telah mengaturnya.

Beberapa Perda dimaksud adalah Perda Kabupaten Tasikmalaya No. 01. Tahun 2000

${ }^{5}$ Diadaptasi dari bagan yang dibuat Cik Hasan Bisri, Pilar-pilar Penelitian Hukum Islam dan Pranata Sosial (Bandung: Lembaga Penelitian IAIN Sunan Gunung Djati, 2001), hlm. 196. 
tentang Pemberantasan Pelacuran; Perda Kabupaten Garut No. 06 Tahun 2000 tentang Pelanggaran Kesusilaan; dan Perda Kabupaten Cianjur No. 21 Tahun 2000 tentang Larangan Pelacuran.

Ketiga Perda dimaksud sengaja dipilih dengan beberapa alasan, yaitu: pertama, masalah yang diatur kesemuanya menyangkut masalah pelacuran atau kesusilaan, ia sangat populer dan erat kaitannya dengan isu penerapan syariat Islam di ketiga lokasi tersebut. Indikatornva, Perda tersebut relatif mendapat respons cukup banyak dari masyarakat (umat Islam) dibandingkan Perda yang lain. Kedua, Perda tentang Kesusilaan atau Pelacuran sudah ada di ketiga lokasi penelitian, sehingga memungkinkan untuk diperbandingkan. Hal itu, berbeda dengan masalah lainnya, seperti Perda tentang Zakat, Infaq, dan Shadaqah meskipun sangat erat kaitannya (terkait langsung) dengan isu penerapan syariat Islam, namun Perda tersebut hanya terdapat di Kabupaten Garut, sementara di daerah lainnya belum mengaturnya.

Dalam analisis berikut, penulis hanya akan menganalisis ketiga Perda tersebut dari segi legislatif drafting-nya (meliputi aspek; struktur Perdanya, tahap penyusunannya, dan substansinya), sedangkan hasil analisis dalam arti yang lebih luas dapat dilihat dalam hasil penelitian. Model alternatif Perda berbasis syariat Islam juga ikut diilustrasikan dalam tulisan ini.

\section{Struktur Perda}

Dari struktur dan bentuk Perda yang dijadikan sampel, dapat dianalisis sebagai berikut: $^{6}$

a. Sisi Penamaan atau judul:

(1) Pada Perda Kabupaten Tasikmalaya No. 01 Tahun 2000 tentang Pemberantasan Pelacuran beserta perubahannya No. 28 Tahun 2000 Tentang Perubahan Pertama Perda Kabupaten Tasikmalaya No. 01 Tahun 2000 Tentang Pemberantasan Pelacuran, ada beberapa hal yang menarik dikemukakan;

a. Penulisan nomor tidak perlu tanda titik dua (:):

b. Nama Perda ini akan lebih baik kalau diberi nama Perda tentang Larangan dan Pemberantasan Pelacuran", karena dalam judul tersebut terkandung unsur larangan/preventifl pencegahan sekaligus mengandung unsur kuratif/ pengobatan/ penanggulangannya. Selain itu, jika dilihat dari substansi pasal-pasalnya terkandung ketentuan larangan.

(2) Pada Perda Kabupaten Garut No. 06 Tahun 2000 tentang Pelanggaran Kesusilaan; Penamaan sudah benar sesuai dengan teknik perancangan yang benar. Namun Perda ini menurut hemat penulis terlalu abstrak dan tidak fokus, sehingga dapat menimbulkan multi tafsir,

${ }^{6}$ Dasar rujukan yang dijadikan pisau analisis adalah:Kepres No. 44 Tahun 1999 Tenlang Teknik Penyusunan Peraturan Perundang-undangan dan Bentuk RUU. RPP, dan R Kepres jo. Kepmendagri dan olonomi Daerah No. 21 Tahun 2001 Tentang Teknik Penyusunan dan Materi Muatan Produk-produk Hukum Daerah jo. Kepmendagri dan Otonomi Daerah No. 22 Tahun 2001 Tentang Bentuk Produk-produk Hukum Daerah. 
di samping ruang lingkup pelanggaran kesusilaan itu sangat luas dan beragam.

(3) Pada Perda Kabupaten Cianjur No. 21 Tahun 2000 tentang Larangan Pelacuran; Penamaan judul sudah benar, namun penggunaan frase "DENGAN RAHMAT ALLAH YANG MAHA KUASA" adalah tidak lazim, karena menurut jukłak yang berlaku, menggunakan frase. "DENGAN RAHMAT TUHAN YANG MAHAESA".

\section{b. Sisi Pembukaan}

(1) Pada Perda Kabupaten Tasikmalaya No. 01 Tahun 2000 tentang Pemberantasan Pelacuran beserta perubahannya No. 28 Tahun 2000 Tentang Perubahan Pertama Perda Kabupaten Tasikmalaya No. 01 Tahun 2000 Tentang Pemberantasan Pelacuran; Ada beberapa catatan sebagai berikut:

a. Dasar pertimbangan Perda tersebut sudah memenuhi ketepatan substantif maupun tarap sinkronisasi vertikal dan horisontal, namun ada beberapa peraturan perundang-undangan yang tidak disebutkan, yaitu: (1) Keputusan Presiden No. 44 Tahun 1999, tentang Teknik Penyusunan Peraturan Perundang-undangan dan Bentuk Rancangan Undang-undang, Rancangan Peraturan Pemerintah, dan Rancangan Keputusan Presiden, terutama Pasal 6 dan 7. (2) Keputusan Keputusan Menteri Dalam Negeri Nomor 84 Tahun 1993 tentang Bentuk-bentuk Peraturan Daerah (Perda), sebab beberapa dasar hukum ini pada vaktu itu masih berlaku; b. Pada frase "Dengan persetujuan," kurang kata "bersama";

c. Letak tulisan Kabupaten semestinya diturunkan sejajar dengan kata Tasikmalaya.

(2) Pada Perda Kabupaten Garut No. 06 Tahun 2000 tentang Pelanggaran Kesusilaan; Ada beberapa catatan sebagai berikut:

a. Ada hal yang terasa ganjil dalam argumen konsideran pada butir (b) yang ditandaskan adanya upaya "pemberantasan" perbuatan asusila, sementara nama/judul Perda ini adalah tentang "pelanggaran" kesusilaan.

b. Dasar pertimbangan hukum secái. substantif kurang fokus dan tidak hierarkhis (butir 4 seharusnya lebih dahulu dișebutkan dari butir 3), dan Peraturan Pemerintah No. 45 Tahiu 1992 (butir 5) sudah tidak berlaku lay. . Sementara Kepres dan Kepmendagri tentang Pembuatan Peraturan Daerah (Perda) tidak ada.

c. Penulisan hurup " $p$ " dengan huruf kecil pada "Dengan persetujuan" adalah "salah," dan kata Kabupaten Garut pada frase Dewan Perwakilan Rakyat Daerah seharusnya diturunkan.

(3) Pada Perda Kabupaten Cianjur Nomor 21 Tahun 2000 tentang Larangan 5 slacuran, dasar hukumnya belum menyebut Keputusan Presiden dan Keputusan Menteri Dalam Negeri tentang Pembuatan Peraturan Daerah (Perda) yang berlaku saat itu (seperti diurai di atas). 


\section{c. Sisi Batang Tubuh}

(1) Pada Perda Kabupaten Tasikmalaya No. 01 Tahun 2000 tentang Pemberantasan Pelacuran beserta perubahannya Nomor 28 Tahun 2000 Tentang Perubahan Pertama Perda Kabupaten Tasikmalaya No. 01 Tahun 2000 Tentang Pemberantasan Pelacuran; Ada beberapa catatan sebagaiberikut:

a. Pada bagian Ketentuan Umum, - terutama bagian Pengertian, perlu ditambahkan pengertian tentang "pemberantasan pelacuran";

b. Ketentuan mengenai objek yang diatur perlu ditambahkan hal-hal mengenai: (1) Rincian atau ruang lingkup pemberantasan pelacuran, baik dalam arti siapa pelaku utamanya, penyedia sarana dan prasarananya, dan intelektual dadernya. (2) Bentuk-bentuk pemberantasan pelacuran;

c. Dalam ketentuan sanksi (Pidana) perlu ditambahkan sanksi administratif berupa pencabutan dan atau penutupan izin usaha yang diindikasikan terkait dengan masalah prostitusi;

d. Pasal tentang penyidikan (Pasal 8) seharusnya diatur lebih dahulu atau sebelum Pasal 7 mengenai ketentuan pidana.

(2) Pada Perda Kabupaten Garut No. 06 Tahun 2000 tentang Pelanggaran Kesusilaan; Ada beberapa catatan sebagaiberikut:

a. Pada Ketentuan Umum Pasal 1. terutama pada butir (d) pengertian Pelanggaran Kesusilaan terlalu abstrak bahkan kabur, sementara ruang lingkup pelangggaran kesusilaannya tidak dirinci secara tegas dan jelas.

b. Ketentuan mengenai objek yang diatur perlu ditambahkan hal-hal mengenai (1) ruang lingkup pemberantasan pelacúran baik dalam .arti-siapa pelaku utamanya, penyedia sarana dan prasarananya, dan intelektual dader-nya. (2) Bentukbentuk pemberantasan pelacuran;

c. Solusi penindakan dan pemberantasan pelanggaran kesusilaan dalam Perda ini kurang jelas. Semestinya hal itu diatur dalam pasal tersendiri.

d. Ketentuan sanksi (Pidana) hanya mengatur masalah tindak pidana kurungan, ancaman dendanya tidak diatur, bahkan sanksi administratif diatur dalam Bab III. Haf itu dapat dikatakan ketentuan penindakan yang "salah kamar";

e. Ketentuan tentang Penyidikan (Pasal 5) seharusnya diatur lebih dahulu atau sebelum Pasal 4 mengenai ketentuan pidana.

(3) Pada Perda Kabupaten Cianjur No. 21 Tahun 2000 tentang Larangan Pelacuran; Ada beberapa catatan sebagai berikut:

a. Pada Ketentuan Umum perlu ditambahkan pengertian tentang Penindakan Pelacruran dan Pembinaan Pelacuran, sebab akan menimbulkan "salah tafsir";

b. Ketentuan mengenai objek yang diatur dalam Perda perlu ditambahkan hal-hal mengenai (1) ruang lingkup perbuatan pelacuran 
(2) Bentuk-bentuk penindakannya;

c. Perda hanya mengatur masalah tindak pidananya, sementara sanksi administratif belum diatur.

\section{d. Sisi Penutup}

(1) Pada Perda Kabupaten Tasikmalaya No. 01 Tahun 2000 tentang Pemberantasan Pelacuran beserta perubahannya No. 28 Tahun 2000 Tentang Perubahan Pertama Perda Kabupaten Tasikmalaya No. 01 Tahun 2000 Tentang Pemberantasan Pelacuran; Ada beberapa catatan sebagai berikut:

a. Pada ketentuan penutup ada hal yang belum diatur yaitu masalah penunjukkan organ atau pihak yang diikutsertakan dalam pelaksanaan Perda ini;

b. Ketentuan Pengundangan dan Pengesahan sudah benar, meskipun perlu dipikirkan adanya paradigma bahwa yang mengesahkan semestinya Ketua DPRD, sesuai dengan amanat amandemen UUD 1945.

(2) Pada Perda Kabupaten Garut No. 06 Tahun 2000 tentang Pelanggaran Kesusilaan: Pada ketentuan penutup ada hal yang belum diatur yaitu masalah penunjukkan organ atau pihak yang diikutsertakan dalam pelaksanaan Perda ini.

\section{Penyusunan Perda}

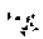

Sesuai dengan rujukan yang berlaku, telaah terhadap Peraturan Daerah (Perda) dalam perspektif proses atau prosedur penyusunan Perda, ${ }^{7}$ difokuskan pada 6 (enam) tahap, yaitu (1) Tahap Perencanaan (2) Tahap Perancangan (3) Tahap Pembahasan (4) Tahap Pengesahan (5) Tahap Pengundangan, dan (6) Tahap Sosialisasi. Telaah terhadap Perda dalam sub kajian ini tidak dilakukan satu persatu dari masing-masing daerah seperti di atas, melainkan dilakukan secara umum terhadap ketiga Perda yang dijadikan sampe!.

\section{a. Tahap Perencanaan}

Pada tahapan perencanaan, setiap proses pembuatan Rancangan Perda seharusnya dilakukan penelitian (research) terlebih dahulu, supaya kebijakan pengaturan ke dalam Perda itu benar-benar didukung data base yang akurat (sesuai aspirasi masyarakat). Dari hasil penelitian itu dibuatlah makalah inti (position paper) sebagai bahan utama pembuatan naskah akademik (academic draft). Berdasarkan investigasi di lapangan, tidak ditemukan bukti bahwa ketiga Peraturan Daerah (Perda) tentang Pelacuran tersebut lahir melalui proses perencanaan yang matang seperti di atas.

Ketiga Perda tentang Pelacuran ini semula dipicu oleh desakan masyarakat yang merasa prihatin terhadap maraknya kegiatan pelacuran dan tindakan asusila lainnya.

'Lihat Kepmendagri dan Otonomi Daerah No. 23 Tahun 2001 Tentang Prosedur Penyusunan Produk Hukum Daerah jo. Kepmendagri dan Olonomi Daerah No. 24 Tahun 2001 Tentang Lembaran Daerah dan Berita Daerah. 
Namun respons dari masyarakat yang memang cukup besar tersebut umumnya sekedar pernyataan secara lisan. Desakan masyarakat tersebut kemudian direspons oleh DPRD dan Pemerintah Daerah. Contoh di Kabupaten Garut dan Cianjur, pada awalnya Perda ini akan diusulkan dan merupakan prakarsa/inisiatif DPRD, namun karena berlarut-laruf tidak ada respon dewan, kemudian "diambil alih" oleh eksekutif. Permasalahan yang muncul menurut salah satu staff di Bagian Hukum, bahwa Perda tentang Pelacuran ini dapat dikatakan tidak mempunyai "induk" atau leading sektor yang jelas, karena masalah pelacuran termasuk wilayah "rebutan" antara Bagian Ketertiban dan Bagian Sosial. Pada tahapan ini, pihak yang terlibat hanyalah Bagian Ketertiban, bagian Sosial, Bagian Hukum serta Sekretaris Daerah. Bukan itu saja, proses pemunculan Raperdaraperda ini juga tidak didukung oleh hasil penelitian dan ketiganya tidak dibarengi dengan draf akademik teriebih dahulu.

\section{b. Tahap Perancangan}

Karena proses riset tidak dilakukan, dan makalah inti serta draf akademik tidak dibuat, maka Tim Asistensi yang sengaja dibuat untuk melakukan perancangan tidak mampu berbuat banyak. Akibatnya mereka cenderung mengambil "jalan pintas" dengan melakukan "studi banding" ke daerah lain yang sudah memiliki Perda sejenis, sehingga tidak dapat dihindarkan-dalam proses penelitian ditemukan-adanya banyak sekali kesamaan di antara ketiga Perda Pelacuran yang dijadikan sampel tersebut. Kegiatan diskusi dan konsultasi memang dilakukan, namun konsultasi dan diskusi yang dilakukan sangat terbatas di antara Tim Asistensi, Bagian Hukum, dan leading sector yang berkaitan dengan masalah pelacuran serta kelompok dan organisasi masyarakat yang sangat terbatas.

\section{c. Tahap Pembahasan}

Ada 2 (dua) tahapan pembahasan yang dilalui oleh ketiga Rancangan Perda tentang Pelacuran tersebut, yaitu (1) pembahasan yang dilakukan di kalangan eksekutif sendiri yang melibatkan perangkat daerah/dinas yang terkait, dan (2) pembahasan dalam sidang DPRD. Pada pembahasan pertama tidak ada pembahasan yang berarti, karena diantara dinas/unit kerja ada semacam sikap untuk tidak terlalu "mencampuri" wilaydh dinas/unit kerja lain. Kecuali itu, umumnya mereka sudah "percaya" dan "menyerahkan sepenuhnya" kepada Tim Asistensi yang sudah dibentuk. Jadi, pembahasan pertama dilakukan sekedar formalitas belaka. Pada pembahasan kedua di DPRD juga tidak ada kajian dan pembahasan berarti. Menurut salah.seorang anggota Tim Asistensi di Kabupaten Garut, anggota DPRD lebih banyak membahas halhal "kecil" yang "tidak perlu" bahkan "salah." Misalnya, mereka bersikukuh menghendaki penggantian frase DENGAN RAHMAT TUHAN YANG MAHA ESA dengan frase DENGAN RAHMAT ALLAH YANG MAHA KUASA.

Pada saat proses pembahasan Rancangan Perda-perda ini DPRD, praktis partisipasi masyarakat tidak dilibatkan, notabene ketiga Perda ini lahir karena dipicu oleh desakan masyarakat. Itu artinya, Perda ini sengaja dibuat hanya untuk memuaskan masyarakat secara kamuflase semata. 


\section{d. Tahap Pengesahan/Pengundangan}

Pada tahapan pengesahan dan pengundangan ini ketiga Perda tentang Pelacuran tersebut sudah dilakukan secara benar, sesuai dengan prosedur dan peraturan peruridang-undangan yang berlaku. Dalam hal ini pengesahan dilakukan oleh Bupati, dan pengundangan dilakukan oleh Sekretaris Daerah melalui Lembaran Daerah dan Berita Daerah. Namun, sesuai dengan semangat dan paradigma baru yang diusung oleh amandemen UUD 1945, sayogyanya pengesahan Perda tersebut dilakukan oleh Ketua DPRD, dan pengundangannya dilakukan oleh Sekretariat DPRD. Sayang sekali pada saat penelitian ini dilakukan RUU tentang Teknik Perancangan dan Penyusunan Peraturan Perundang-undangan belum berhasil disyahkan. Sebab, harapannya RUU itulah yang bakal menjadi payung bagi pembuatan peraturan termasuk peraturan perundangan tingkat daerah.

\section{e. Tahap Sosialisasi}

Pada tahap sosialisasi inipun masih jauh dari harapan, terbukti pada saat peneliti berusaha mendapatkan Perda yang diinginkan, peneliti harus melewati beberapa "prosedur" tertentu, belum lagi masalah kesemrawutan administrasi di daerah. Dari ketiga lokasi penelitian, Kabupaten Garut termasuk yang paling tertib untuk masalah pengarsipannya. Hal itu berarti, tingkat akses publik untuk mendapatkan produk-produk hukum daerah masih sangat rendah. Bagian Hukum di ketiga lokasi penelitian juga mengakui kekurangannya dalam hal sosialisasi produkproduk hukum daerah tersebut. Selama ini mereka hanya melakukannya dengan mencetaknya dalam jumlah yang sañgat terbatas, alasan klasik yang mereka kemukakan adalah masalah keterbatasan anggaran. Untuk Kabupaten Cianjur patut dipuji, karena pada tahap sosialisasi ini sudah mulai mencoba menggunakan media internet, meskipun belum efektif betul.

\section{Substansi Perda}

Telaah aspek substansi Perda pada dasarnya menyoroti Batang Tubuh dari masing-masing Perda tentang Pelacuran tersebut. Namun karena secara singkat sudah dibahas dalam telaah struktur dan bentuk Perda sebelumnya, maka pada sub-bagian ini lebih difokuskan pada analisis materi yang diatur dalam masing-masing Perda.

Setelah mencermati dan mengkaji substansi materi dari beberapa Perda dimaksud, ada beberapa catatan yang dapat dikemukakan, yaitu:

a. Terdapat banyak kesamaan isi dari ketiga Perda tersebut, yang berbeda hanyalah penamaan atau judulnya saja. Perda yang dari Kabupaten Tasikmalaya diberi nama Perda tentang "Pemberantasan Pelacuran," yang dari Kabupaten Garut berjudul Perda tentang "Pelanggaran Kesusilaan," dan yang dari Kabupaten Cianjur berjudul Perda tentang "Larangan Pelacuran". Adanya banyak hal kesamaan tersebut ternyata bukan tanpa sengaja, para perancang dan penyusun Perda tersebut mengaku 'saling berkunjung' dan melakukan 'studi banding' dalam proses penyusunannya. Jika dilihat dari waktu pengundangannya ternyata Perda dari Kabupaten Garut diundangkan lebih 
dahulu (17 Pebruari 2000), kemudian Kabupaten Cianjur (14 Nopember 2000), dan Kabupaten Tasikmalaya (8 Desember 2000).

b. Dalam Perda Kabupaten Tasikmalaya yang diberi judul "Pemberantasan Pelacuran" ternyata tidak ditemukan pengertian tentang pemberantasan pelacuran itu sendiri. Ruang lingkup dan bentuk-bentuk upaya pemberantasan pelacuran juga belum diatur. Hal itu tentu saja akan mengaburkan efektifitas pencapaian tujuan dari Perda itu sendiri, yakni "memberantas" pelacuran. Sanksi administratif berupa pencabutan dan atau penutupan izin usaha juga belum diatur dalam ketentuan sanksi. Pengaturan sanksi administratif dalam Bab tentang KETENTUAN PENINDAKAN dapat dikategorikan "salah kamar" dan dirasakan kurang tegas. Penegasan ketentuan sanksi administratif tersebut dirasakan penting, mengingat selama ini dalam proses razia atau operasi pelacuran, seringkali terjadi "kucingkucingan" antara petugas dengan germo dan atau pelacur. Beberapa waktu setalah razia, praktek pelacuran tersebut muncul kembali. Hal itu terjadi antara lain karena lokasi yang dijadikan mangkal para pelacur dan germo-misalnya warung atau hotel, tidak pernah diusik oleh petugas.

Perda Kabupaten Garut yang berjudul "Pelanggaran Kesusilaan" juga pengertian tentang pelanggaran kesusilaan masih terlalu abstrak bahkan dapat dikatakan kabur. Ruang lingkup pelangggaran kesusilaannya juga tidak dirinci secara tegas dan jelas. Akibatnya, solusi penindakan dan pemberantasan terhadap pelanggaran kesusilaan juga kurang jelas. Hal itu tentu saja akan mengaburkan efektifitas pencapaian tujuan dari Perda itu sendiri, yakni memberantas segala bentuk pelanggaran kesusilaan. Ketentuan sanksi dalam Perda ini juga hanya memuat ancaman pidana kurungan, ancaman denda tidak diatur. Pengaturan sanksi administratif dalam Bab tentang KETENTUAN PENINDAKAN selain dirasakan kurang tegas juga dapat dikategorikan "salah kamar," yang salah satu akibatnya adalah masalah kepastian hukum dan terjadinya kelemahan dalam penegakkannya.

Demikian halnya pada Perda Kabupaten Cianjur tentang "Larangan Pelacuran". Dalam ketentuan umum belum ada pengertian tentang penindakan pelacuran dan pembinaan pelacuran. Ketidakjelasan pengertian tersebut dapat menimbulkan "salah tafsir" dalam penegakkannya. Ruang lingkup perbuatan pelacuran dan bentuk-bentuk penindakan dan pembinaannya juga belum diatur secara rinci dan jelas. Padahal, mengingat fungsi Perda sebagai peraturan pelaksana-dari peraturan di atasnya serta untuk menampung kondisi khusus dari daerah yang bersangkutan, maka isi Perda itu semestinya mengatur lebih rinci. Selain itu Perda ini juga hanya memuat ancaman pidana kurungan dan denda. Pengaturan sanksi administratif justru diatur dalam Bab tentang PENGAWASAN, PENINDAKAN, DAN PEMBINAAN. Selain dirasakan kurang tegas, hal itu juga dapat dikategorikan "salah kamar". 
c. Secara umum, materi muatan ketiga Perda tersebut belum menunjukkan kesesuaian antara isi dengan dasar filosofis, sosiologis, dan politis yang melatarbelakanginya. Maka dapat diprediksikan, pada tataran pelaksanaannya ketiga Perda tersebut akan menghadapi beberapa tantangan. Beberapa tokoh agama yang diwawancarai juga memandang bahwa substansi Perda tersebut masih jauh dari harapan mereka, terutama berkaitan dengan ancaman hukuman bagi pelacur dan pasangannya yang dinilai "terlalu ringan." Tidak heran jika hal itu memunculkan kepesimisan di kalangan mereka akan keefektifan Perda tersebut dalam upaya pemberantasan pelacuran.

\section{Model Pembuatan Perda yang Ditawarkan?}

Untuk melakukan rekayasa model penyusunan Perda yang diharapkan berlaku di masa depan (ius constituendum), terlebih dahulu perlu dideskripsikan kembali model penyusunan/perancangan Perda yang selama ini ada dan berlaku, beserta titik-titik kelemahannya, untuk kemudian dicari altematif model yang dapat ditawarkan di masa depan. Selain itu, beberapa permasalahan praktis yang ditemukan di lapangan, dan perkembangan mutakhir yang berkaitan dengan aspirasi dan tuntutan masyarakat juga harus dipertimbangkan.

Berdasarkan telaah terhadap rujukan tentang Perda dan rujukan tentang prosedur dan mekanisme penyusunan Perda pada pembahasan sebelumnya, ada beberapa catatan yang layak dijadikan acuan untuk penyusunan model baru proses penyusunan Perda di masa depan, yaitu:

Pertama, jelas terlihat bahwa rujukan yang ada masih menganut paradigma lama yang cenderung executive heavy. Kecenderungan dominasi kekuatan eksekutif tersebut misalnya jelas terlihat dalam Undang-undang tentang Pemerintahan Daerah. Gubernur/Bupati/ Walikota, di samping mempunyai kekuasaan eksekutif, ia juga mempunyai (atau boleh dibaca, mencampuri) kekuasaan legislatif dan yudikatif (Lihat: Pasal 19 ayat (1) butir $d$ dan f; Pasal 43 butir g; Pasal 69; Pasal 70; Pasal 73 ayat (1)).

Kuatnya kekuasaan eksekutif juga terlihat dalam Keputusan Presiden dan Keputusan Menteri Dalam Negeri dan Otonomi Daerah yang mengatur bahwa yang mengesahkan Perda adalah Gubernur/Bupati/Nalikota dan yang mengundangkan Perda ke dalam Berita dan Lembaran Daerah adalah Sekretaris Propinsi/Kabupaten/Kota. Padahal jika merujuk pada semangat dan perubahan yang terjadi pasca amandemen UUD 1945, pihak yang mengesahkan semestinya adalah Sekretariat DPR/DPRD, dan yang mengundangkan Perda ke dalam Berita dan Lembaran Daerah juga semestinya Sekretaris DPRD.

Kedua, rujukan prosedur penyusunan Perda tersebut tidak secara tegas menekankan pentingnya proses penelitian (riset), pembuatan makalah inti (position paper), dan draf akademik (academicdraft) yang semestinya mendasari setiap perancangan/ penyusunan Perda. Padahal, agar setiap Perda yang dikeluarkan benar-benar mampu menjawab permasalahan yang terjadi di tengah-tengah masyarakat, dan tidak berientangan dengan nilai-nilai yang beriaku 
di tengah-tengah masyarakat, serta tidak menimbulkan gejolak di tengah-tengah masyarakat, proses penelitian secara ilmiah adalah niscaya adanya.

Ketiga, rujukan prosedur penyusunan Perda tersebut juga tidak secara tegas membuka partisipasi publik seluas-luasnya dalam proses penyusunan Perda, mulai dari tahapan perencanaan, perancangan, permbahasan, hingga sosialisasi. Dalam penyelenggaraan pemerintahan daerah yang demokratis, penyusunan Perda, perlu mengikutsertakan masyarakat, misalnya melalui riset, dengar pendapat, diseminasi aspirasi, pengawasan, dan sebagainya, dengan tujuan agar dapat mengakomodasikan kepentingan masyarakat luas tersebut untuk dituangkan dalam Perda. Peran serta masyarakat tersebut akan mempermudah sosialisasi dan penerapan substanisi apabila Perda itu sudah ditetapkan dan diundangkan.

Keempat, di era demokratisasi dan otonomi dewasa ini, beberapa ketentuan Keputusan Presiden dan Keputusan Menteri Dalam Negeri dan Otonomi Daerah tersebut dirasakan cukup kaku (rigid) untuk mampu mengimbangi dinamika aspirasi masyarakat daerah. Semakin luasnya kewenangan daerah sesuai dengan konsepsi otonomi luas, berbanding lurus dengan semakin kompleksnya urusan dan permasalahan di daerah, dan itu berarti harus semakin responsif dan proaktifnya para penyelenggara pemerintahan di daerah, termasuk dalam proses penyusunan regulasi daerah. Pedoman penyusunan Perda yang rigid dan kaku, akan menjadi salah satu faktor penghambat yang cukup berarti bagi para penyelenggara pemerintahan di daerah. Memang, sebuah kepastian hukum, setiap produk hukum harus dirancang dengan format dan teknis penulisan yang baik dan benar, serta berdasarkan prosedur yang sah, sehingga dapat dipertanggungjawabkan. Untuk itu periu adanya standardisasi bentuk produk hukum daerah. Namun demikian, standardisasi yang kaku dan tidak mampu mengimbangi perkembangan aspirasi masyarakat, justru akan melahirkan "penolakan" dan "pelanggaran" dari masyarakat sendiri, terbukti dengan banyaknya Perda yang dianggap "bermasalah" oleh Departemen Dalam Negeri.

Akibat dari rujukan yang masih memiliki beberapa kelemahan seperti itu, ternyata juga melahirkan Perda yang tidak kalah "lemahnya". Dari perspektif legislative drafting ketiga Perda yang dijadikan kajian dalam makalah ini juga memiliki banyak kelemahan. Beberapa kelemahan tersebut antara lain:

Pertama, paradigma pembuatan ketiga Perda tersebut masih kuat dan kental nuansa executive heavy-nya. Salah satu indikatomya adalah Perda tersebut semuanya berasal dari inisiatif eksekutif. Padahal, ketiga Perda tersebut lahir di era otonomi dan berada pada era amandemen UUD 1945. Para pembuat Perda tersebut seharusnya sudah memahami dan mengakomodasi paradigma baru dalam legislative drafting;

Kedua, mengingat masih banyaknya kesalahan dari aspek legislative drafting pada ketiga Perda tersebut, secara umum dapat dikatakan bahwa para pembuat Perda tersebut (èksekutif dan legislatif daerah) belum memahami secara baik dan benar pedoman penyusunan Perda yang sedang dan terus diperbaiki ini;

Ketiga, secara substantif, ketiga Perda tersebut belum mengikuti prinsip-prinsip pembuatan Perda yang baik dan demokratis. 
Hal itu antara lain dapat dilihat dari adanya kenyataan di bawah ini;

1. Ketiga Perda tersebut tidak didasarkan pada penelitian (research) formal yang serius;

2. Masyarakat dan stake holders belum dilibatkan secara penuh, mulai dari tahapan perencanaan sampai tahapan sosialisasi;

3. Public hearing atas ketiga Perda masih sangat terbatas;

4. Sosialisasi ketiga Perda tersebut juga masih sangat terbatas dan cenderung menggunakan cara-cara konvensional.

Keempat, secara umum, motivasi yang mendasari penyusunan Perda tersebut masih mengedepankan dimensi rechtsmatigheid, sekedar untuk memenuhi tuntutan masyarakat, sehingga Perda tersebut dibuat "asal jadi." Akibatnya, dimensi doelmatigheidnya terabaikan.

Dari pemaparan di atas, secara teoritis dapat dikatakan bahwa politik hukum dan perundang-undangan yang menjadi rujukan penyusunan Perda termasuk Perda yang dihasilkannya masih condong pada paradigma "state oriented" daripada "public oriented." Kecenderungan seperti itu pada gilirannya dapat mengesampingkan "faham konstitusi" yang menekankan perlunya pembatasan kekuasaan, dan kekuasaan harus tunduk pada hukum. ${ }^{8} \mathrm{Hal}$ itu juga dapat dimaknai terjadinya deviasi terhadap teori "Rechtsstaaf" terutama pada prinsip pemisahan kekuasaan secara tegas dalam suatu negara. Kenyataan tersebut juga dapat dimaknai bahwa konstitusi dan perundang- undangan Indonesia masih memposisikàn eksekutif lebih dominan dari pada legislatif. Padahal, sejarah telah membuktikan bahwa kerugian atau dampak negatif akibat dari dominan eksekutif yang berlebihan, tanpa diimbangi mekanisme checks and balances sangat berat dirasakan di mana-mana.

Berdasarkan deskripsi tentang kelemahan model rujukan penyusunan Perda yang berlaku (sekarang) tersebut, dapat diinventarisasi beberapa solusi teroretis untuk penyusunan model alternatif pembuatan Perda berbasis syariat Islam untuk masa depan, yaitu:

1. Pemegang kekuasaan membentuk peraturan harus bertumpu pada kekuasaan legislatif (legislative power), namun tetap tersedia mekanisme cheks and balances;

2. Konsiderannya harus didasarkan pada pertimbangan yang komprehensif dan mendalam dari aspek filosofis, yuridis, politis, ekonomis, sosiologis, maupun aspek ekologis.

3. Substansinya harus benar-benar disesuaikan dengan tuntutan dan aspirasi masyarakat (bisa dibaca, sesuai syariat lslam);

4. Output peraturannya harus responsif, -populistik, demokratis, dan akomodatif;

5. Dengan kata lain (butir $1-4$ di atas), harus memiliki standardisasi tertentu dari aspek struktur, prosedur, format, substansi, maupun teknis penulisannya, namun tetap mampu mengimbangi tuntutan aspirasi masyarakat dan perkembangan zaman.

Untuk mempermudah pemahaman, berikut ini model alternatif pembuatan Perda

"Moh. Mahfud MD., Politik Hukum Di indonesia (Jakarli: !.P3ES, 1998), him 54. 62. 
Tabel 2

Perbandingan Proses Pembuatan Perda

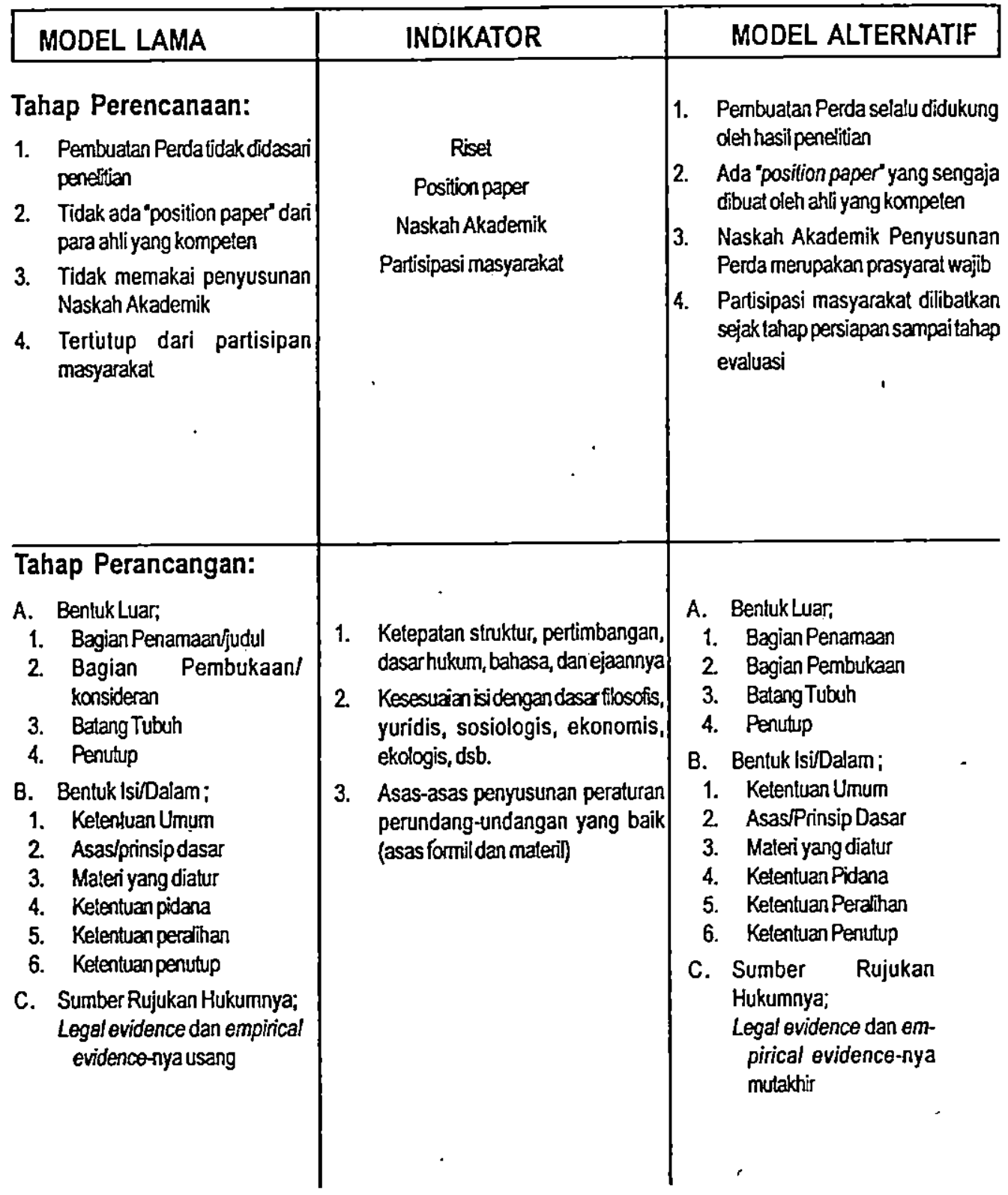




\begin{tabular}{|c|c|c|}
\hline $\begin{array}{l}\text { Tahap Pembahasan: } \\
\text { 1. Pembahasan dilakukan secara tertutup } \\
\text { 2. Tidak melibatkan masyarakat }\end{array}$ & $\begin{array}{l}\text { Pembahasan } \\
\text { Partisipasi masyarakat }\end{array}$ & \begin{tabular}{|l} 
1. \\
Pembahasan dilakukan secara \\
terbuka \\
2. $\begin{array}{l}\text { Melibatkan stakeholders } \\
\text { masyarakat }\end{array}$
\end{tabular} \\
\hline $\begin{array}{l}\text { Pengesahan dan } \\
\text { Pengundangan: } \\
\text { 1. Pengesahan deh Gubemurl } \\
\text { Bupati/Walikota } \\
\text { 2. Pengundangan oleh } \\
\text { Sekretaris Daerah }\end{array}$ & $\begin{array}{l}\text { Pengesahan } \\
\text { Pengundangan }\end{array}$ & 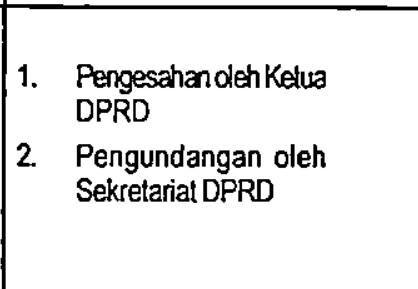 \\
\hline $\begin{array}{l}\text { Tahap Sosialisasi: } \\
\text { 1. Sosialisasidilakukanpada segmendan } \\
\text { 2. Sulit diakses } \\
\text { 3. Menggunakan caracarakonvensional }\end{array}$ & $\begin{array}{c}\text { Masyarakat mengetahuidanmudah } \\
\text { mendapatkan Produk Perda }\end{array}$ & $\begin{array}{l}\text { 1. Sosialisasi dilakukan pada } \\
\text { segmen yang yang tak lerbatas } \\
\text { 2. Mudah diakses publik } \\
\text { 3. Menggunakan cara yang } \\
\text { moderen }\end{array}$ \\
\hline
\end{tabular}

Seluruh tahapan dan kriteria model alternatif penyusunan Perda tersebut dimaksudkan dalam perspektif pembuatan Perda yang berbasis syariat Islam, karena proses transformasi Hukum Islam juga harus diawali oleh penelitian dan inventarisasi materi hukumnya yang hidup dalam masyarakat dengan senantiasa memperhatikan perubahan yang terjadi dan selalu melibatkan partisipasi masyarakat.

Lebih dari sekedar itu, dalam pembuatan Perda berbasis syariat islam, setiap tahapan pembuatan di atas harus dimaknai lebih serius, karena selain membutuhkan kerja keras untuk membahasakan nilai-nilai syariat Islam ke dalam naskah hukum, dibutuhkan pula kesepakatan (ijma) di kalangan umat Islam sendiri serta kesediaan untuk "kompromi" dan "berintegrasi" dengan tatanan hukum lain, termasuk tatanan hukum nasional. Dengan kata lain, dalam proses pembuatan Perda berbasis syariat Islam; selain diperlukan kemampuan tentang legislative drafting, diperlukan pula kemampuan dalam istimbat hukum serta pemahaman mendalam dan komprehensif tentang sistem dan dinamika hukum, baik hukum Islam, hukum nasional, maupun hukum adat. Sebab, jika salah memaknai dan menyikapi, misalnya sematamata didasarkan pada kepentingan sesaat kedaerahan (eforia kedaerahan) dan tendensi untuk menonjolkan identitas kelompok, 
kepentingan, dan agama semata-mata, maka yang terjadi bukan pemberlakuan dan pembentukan hukum yang responsifharmonis-demokratis, tetapi yang terjadi adalah hukum elitis, anarkis dan cenderung ke egoisme kedaerahan.

\section{Simpulan}

Secara umum, model rujukan pembuatan Perda yang ada dan berlaku sekarang cenderung executive heavy dan tidak secara tegas menekankan pentingnya proses penelitian (riset) dan partisipasi publik seluasluasnya dalam proses penyusunan Perda. Model rujukan tersebut juga dirasakan cukup kaku (rigid) untuk mampu mengimbangi dinamika aspirasi masyarakat di era otonomi daerah.

Terhadap Perda yang dijadikan sampel dalam kajian ini, secara substantif proses pembuatannya belum mengikuti prinsipprinsip pembuatan peraturan perundangundangan yang baik dan demokratis. Simpulan tersebut didasari oleh temuan bahwa proses pembuatan ketiga Perda tersebut tidak didasari oleh penelitian dan pembuatan naskah akademik yang serius, serta partisipasi publik dalam penyusunannya juga masih sangat terbatas. Dalam perspektif legislative drafting-nya juga ditemukan format dan sitematika yang tidak benar.

Alternatif model pembuatan Perda berbasis syariat Islam yang ditawarkan idealnya harus: (1) bertumpu pada kekuasaan legislatif (legislative power) namun tetap tersedia mekanisme cheks dan balances; (2) responsif, populistik, dan akomodatif; (3) menekankan pentingnya pertimbangan yang komprehensif dan mendalam dari aspek filosofis, yuridis, politis, ekonomis, sosiologis, maupun aspek ekologis; (4) harus memiliki standard tertentu dari aspek prosedur, format, maupun teknis penulisannya, namun tetap mampu mengimbangi tuntutan aspirasi dan perkembangan zaman.

\section{Daftar Pustaka}

Abdullah, Taufik dan Sharon Siddique, Tradisi dan Kebangkitan Islam di Asia Tenggara, Jakarta: LP3ES,1989.

Al-Ghazali, al-lqtishaad fi al-l'tiqaad, Bairut: Dar al-Kutub al-IImiyyah,1988. Ihya Ulumu al-Din, Kairo: Masyhad al-Husaini,t.t.

al-Maududi, Abul A'la, The Islamic Law and Constitution, diterjemahkan, Hukum dan Konsrtitusi; Sistem Politik Islam, Bandung: Mizan, 1994.

al-Mawardi, Abu al-Hasan, al-Ahkaam alShulthaaniyyah, Bairut: Dar al-Fikr,t.t.

al-Nabhani, Taqiyuddin, "Nizham al-Hukmi fi al-Islam," diterjemahkan, Sistem Pemerintahan Islam, Bangil: al-lzzah, 1996.

al-Ra'is, Dliya al-Din,al-Islam wa al-Khilafah fi al-Ashri al-Hadits; Naqd Kitab al-Islam wa Ushul al-Hukm, Kairo: dar alTurats,t.t.

Anonimus, Kompilasi Hukum Islam, Bandung: Humaniora Utama Press.

Anshari, Endang Saefuddin, Piagam Jakarta 22 Juni 1945, dan Sejarah Konsensus 
Nasional Antara Nasionalis Islami dan Nasionalis "Sekuler" Tentang Dasar Negara Republik Indonesia, Bandung: Pustaka, 1991.

Asad, Muhammad, Minhaj al-Islam fial-Hukmi, diterjemahkan, Sebuah Kajian Tentang Sistem Pemerintahan Islam, Bandung: Pustaka,I985.

Attamimi, Abdul Hamid. S., "Peranan Kepres Dalam Penyelenggarakan Pemerintah Negara," Disertasi Ul Jakarta, 1990.

, "Der Rechtsstaat Republik Indonesia dan Perspektifnya Menurut Pancasila dan UUD 1945," Makalah dalam Seminar Dies Natalis UNTAS Jakarta ke 42, 9 Juli 1994.

Azhary, Negara Hukum Indonesia, Jakarta: UI Press, 1995.

Basyir, Ahmad Azhar, Pokok-pokok Persoalan Filsafat Hukum Islam, Yogyakarta: UII, 1984.

Dick, Robert. C., Legal Drafting, the corswell Company Limited, 1972.

Dickerson, Reed, The Fundamentals of Legal Drafting, Little, Boston, Toronto: Brown and Company, 1986.

Esposito, John L., "Islam and Politics," diterjemahkan; Islam dan Politik, Jakarta: Bulan Bintang. 1990.

Ibnu Taiymiyyah, al-Siyasah al-Syar"iyyah fi Ishlah al-Ra'l wa al-Ra'iyyah, Lebanon: Dar al-Kutub al-Arabiyyah,t.t.

Khatami, Mohammad, Membangun Dialog Antar Peradaban, Bandung: Mizan, 1998.
Kusumaatmadja, Mochtar, Fungsir dan Pembangunan Hukum. Dalam Pembangunan Nasional, Bandung: Binacipta, 1976.

, Hukum, Masyarakat, dan Pembinaan Hukum Nasional, Bandung: Binacipta, 1976.

Levy, Ruben, The Social Structure of Islam, diterjemahkan, Susunan Masyarakat Islam, Jakarta: Pustaka Firdaus, 1986.

Lubis, M. Solly, Landasan dan Teknik Perundangan-undangan, Bandung: Mandar Maju, 1989.

M, Sri Soemantri, "Beberapa catatan Terhadap Proposal Penelitian Tentang Aspek Hukum Inisiatif DPR Dalam Penyusunan UU," Makalah tidak diterbitkan, 1998.

Manan, Bagir, Dasar-Dasar PerundangUndangan Indonesia, Jakarta: IndHill.co., 1992. , Menyongsong Fajar Otonomi Daerah, Yogyakarta: PSH. Fak. Hukum. UII, 2001.

, "Penelitian di Bidang Hukum," Dalam Jurnal Hukum, Bandung: Puslitbangkum-UNPAD, Nomor Perdana: 1- 1999. Sistem dan Teknik Pembuatan Peraturan Perundang-Undangan Tingkat Daerah, Bandung: LPPM UNISBA, 1995.

MD, Moh Mahfud., Politik Hukum Di Indonesia, Jakarta: LP3ES, 1998

Prakoso, Djoko, Proses Pembuatan Peraluran 
Daerah, Jakarta: Ghalia Indonesia, 1985.

Pulungan, Suyuthi, Fiqh Siyasah; Ajaran

Sejarah dan Pemikiran, Jakarta: Rajawali, 1994.

Rosenthal, E.I.J., Islam in The Modem National State, Cambridge at The University Press, 1965.

Soejito, Irawan, Teknik Membuat UndangUndang, Jakarta: Pradnya Paramita, 1988.

Soekanto, Soerjono, Pengantar Penelitian Hukum, Jakarta: UI-Press, 1986.

Soeprapto, Maria Farida Indrati, IImu
Perundang-undangan Dasar-Dasar dan Pembentukannya, Yogyakarta: Kanisius, 1998.

Wa, Mohamed S.El, "On The Political System of Islamic State,". diterjemahkan, Sistem Politik Dalam Pemerintahan Islam, Surabaya: Bina IImu, 1983.

Widodo, L.Amin, Fiqih Siyasah Dalam Hubungan Intemasional, Yogyakarta: Tiara Wacana, 1994.
Peraturan Perundang-undangan:

Amandemen I, II, III, dan IV UUD 1945.

\section{0}

